\title{
Om historiske og nutidige begreber brugt til at beskrive Lili Elvenes
}

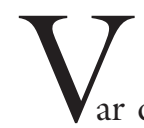

ar den historiske person

Lili Ilse Elvenes, bedre kendt som Lili Elbe, en transkønnet eller en interkønnet person? Det spørger Bente Rosenbeck og Yvonne Mørck sig selv om efter at have besøgt hendes grav i Dresden og være blevet konfronteret med flere forskellige udsagn fra bl.a. Sachsens ligestillingsminister, den tyske og den danske Wikipedia-side, lederen af Lili Elbe Archiv i Dresden, og den tyske histo-riker Sabine Meyers publicerede ph.d.-afhandling (Meyer 2015). Det samme spørgsmål har en del andre forskere, som har beskæftiget sig med Elvenes' livshistorie, stillet sig i tidens løb, og de fleste har konkluderet, ligesom Rosenbeck og Mørck, at det er meget usandsynligt eller biologisk set umuligt, at Elvenes skulle have været interkønnet - eller hermafrodit, som var den historiske betegnelse, der blev brugt i samtiden.

Et interessant spørgsmål i den forbindelse er dog, hvad man overhovedet forstår ved de begreber, der spørges til? Lili Elve- 
nes status som den første transkvinde i verden, der fik foretaget en kønskorrigerende operation, såvel som spørgsmålet om, hvorvidt hun var trans- eller interkønnet, er som regel blevet stillet ud fra nutidige definitioner af interkønnethed og transkønnethed. I dag forbinder de fleste mennesker en transkvindes medicinske transition med behandling med østrogener, der bl.a. gør huden blødere og xndrer kroppens fedtfordeling, så hofterne bliver bredere, og med operationer, hvor brysterne forstørres, og man danner en neo-vagina. Interkønnethed forbindes med medfødte fysiske tilstande, hvor en person har en anatomi, der biologisk og medicinsk bliver betegnet som en blanding eller kombination af mandlig og kvindelig. Det kan f.eks. være, at et barn fødes med genitalier, som sundhedspersonalet ikke genkender som tydeligt værende penis og testikler eller klitoris og vagina; men det kan også være andre ikke-synlige fænomener, som f.eks. når en person med en krop, der betragtes som normalt kvindelig, viser sig at have kønskromosomerne XY. Ud fra disse definitioner har de fleste historikere defineret Lili Elvenes som en mandlig person, der skiftede social og juridisk kønsposition ved at gennemgå en række forskellige underlivsoperationer, men som ikke var født med en interkønstilstand.

Disse definitioner blev dog først indført i lægevidenskab i 1950'erne og 60'erne og eksisterede ikke i Lili Elvenes' samtid. I de selvbiografiske og lægevidenskabelige beretninger om personer, der har skiftet socialt og juridisk køn mellem år 1900 og begyndelsen af 1970'erne, som jeg har analyseret i min ph.d.-afhandling Fleshing Out the Self (2017), brugte skribenterne i stedet betegnelserne hermafroditisme og transvestisme. Disse begreber er forløbere for, men ikke identiske med, de nutidige betegnelser interkønnethed og transkønnethed. Med dette in mente ser jeg derfor på Lili Elvenes' livshistorie og beretningen om den $\mathrm{i}$ bogen Fra Mand til Kvinde (1931) ud fra en lidt anden synsvinkel end Rosenbeck,
Mørck og mange andre historikere og biografer har gjort. De fleste historikere og biografer har således overvejet, om bevarede lægefaglige dokumenter tyder på, at Elvenes var interkønnet eller ej, om den beskrivelse, som forfatterne af Fra Mand til Kvinde giver af hendes anatomi, kan være af en interkønnet krop eller ej, og om henholdsvis læger og forfattere har været troværdige i fremstillingerne. I mit ph.d.-projekt har jeg i stedet i forhold til Elvenes'sag været mere interesseret $i$ at besvare spørgsmålene: Hvad mente Elvenes og hendes medforfattere, når de beskrev Lili som hermafrodit? Hvordan er denne beskrivelse relateret til samtidens lægevidenskabelige og populære opfattelser af hermafroditisme? Og hvad kan være årsagen til, at ikke kun Lili, men flere transkvinder i hendes samtid både før og efter udgivelsen af Fra Mand til Kvinde, hævdede, at de var hermafroditter?

Danske og internationale historiske kilder viser, at både vestlige lægefaglige eksperter og personer, der gennemgik en social, juridisk, og/eller medicinsk transition i første halvdel af det 20. århundrede, havde en anden opfattelse end den i dag udbredte af, hvornår en person var en mand eller en kvinde, og hvordan en person kunne 'skifte køn'. I 1920'erne og 30'erne var der både blandt læger og lægmænd internationalt set stor interesse for personer, som blev betragtet som værende hermafroditter, og for, hvordan sådanne personer kunne skifte køn fra kvinde til mand eller omvendt. I pressen blev der med jævne mellemrum bragt historier om personer, der spontant begyndte at skifte køn, dvs. at de hævdedes pludselig at udvikle fysiske træk, som blev forbundet med en anden kønskategori end den, de var blevet tildelt ved fødslen (Oram 2007; Tebbutt 2014; Holm 2017, 286).

Lili Elbes historie, som den er præsenteret i bogen Fra Mand til Kvinde, er præcis sådan en slags historie. Her beskrives det, hvordan hovedpersonen Andreas først opfinder et kvindeligt alter ego sammen med 
sin hustru Grethe. Dette alter ego kalder de Lili, og hun står model til Grethes malerier og får gradvist sit eget liv. Derefter begynder Andreas-Lilis krop at forandre sig og udvikle, hvad der beskrives som en mere kvindelig form, og hovedpersonen har i stigende grad en oplevelse af at være to personer, der er fanget og kæmper med hinanden i den samme krop. Denne tilstand gør Andreas-Lili deprimeret og mere og mere desperat, og han-hun forsøger længe at finde hjælp hos forskellige læger, da han-hun føler, at det ikke vil være muligt at blive ved med at leve sådan. På dette tidspunkt i historien møder Andreas-Lili, som Rosenbeck og Mørck har beskrevet, doktor Werner Kreutz, der erklærer, at årsagen til hans-hendes oplevelser og fysiske forandringer er, at Andreas-Lili har både kvindelige og mandlige organer (Hoyer 1931, 17). At dette er tilfældet, har hovedpersonen allerede længe haft mistanke om ud fra at læse den nyeste lægevidenskabelige litteratur om seksualvidenskab:

"[I]ntet af alt det, der handlede om almindelige Mænd og Kvinder, kunde passe paa min Tilstand ...... Efterhaanden kom jeg til den Overbevisning, at jeg baade var Mand og Kvinde, og at det var Kvinden, der var i Færd med at tage Magten i mit Legeme ...... kun denne Teori kunde forklare de fysiske og psykiske Forstyrrelser, der voldte mig flere og flere Kvaler" (Hoyer 1931, 58).

Han-hun bliver derfor lykkelig, da professor Kreutz tilbyder at hjælpe ved at udføre en række operationer, der bl.a. inkluderer en transplantation af ovarier fra en yngre kvinde til hovedpersonen. Ifølge Kreutz vil dette have en foryngende virkning, den fornyede produktion af kvindelige hormoner vil komplettere den delvise fysiske udvikling i kvindelig retning, de mandlige fysiske træk vil forsvinde, og Lili vil kunne leve videre som en fuldstændigt sund kvinde (ibid.).

I Fra Mand til Kvinde såvel som i andre af samtidens populære beretninger om personer, der spontant begynder at udvikle sig i en ny kønslig retning, bliver hovedpersonen dermed hjulpet af medicinske eksperter, som kender til de nyeste teorier. Disse teorier forbinder hormonproduktion med kønsudvikling, og hævder, at man ved at foretage fysiske og hormonundersøgelser i kombination med psykologiske tests kan bestemme en persons 'virkelige køn'. Derudover skildres det i bogen og i andre populære beretninger, hvordan nye kropsmodifikationsteknologier udviklet efter Første Verdenskrig dels har gjort specialister i stand til gennem kirurgi at fjerne allerede udviklede kønskarakteristika, der ikke stemmer overens med deres patienters psykologiske køn. Og endelig berettes der om en ny teknologisk mulighed for at styre patienters kroppes kønsudvikling i en bestemt retning igennem kønskirteltransplantationer (dvs. at indoperere ovarier eller testikler i bughulen efter fjernelse af de medfødte kønskirtler) (Oram 2007, Chapter 5; Tebbutt 2014, 29-30, Chapters 2 \& 3; Hoyer 2004). Den oplevelse af at være to personer i samme krop, som Andreas-Lili beskrives at have i Fra Mand til Kvinde, understøttedes dermed af og var i fuld overensstemmelse med udbredte beretninger om internationale medicinske teorier. I Danmark stod sådanne teorier stærkt, ikke mindst gennem seksualbiolog og formand for Retslægerådet Knud Sands forskning (Holm \& Bülow 2013).

Ifølge disse teorier blev al kønsudvikling, fysisk såvel som psykisk og adfærdsmæssigt, determineret af kønskirtlernes hormonproduktion. Omkring udgivelsen af Fra Mand til Kvinde var hormoner og deres funktioner i kroppen stadig et forholdsvis nyt forskningsområde, og det var først i årene efter, at biokemikere blev i stand til at syntetisere de såkaldte kønshormoner, hvorved de fandt ud af, at der fandtes mere en blot ét hanligt og ét hunligt hormon, og at alle pattedyr producerer alle hormonerne i varierende mængde. På det tidspunkt, hvor bo- 
gen blev skrevet, var de førende lægefaglige eksperters teori stadig, at produktionen af ét hunligt eller ét hanligt hormon i en menneskekrop forårsagede en kønsudvikling i kun én af to mulige normale retninger: til en kvindelig eller en mandlig krop. Sand og hans udenlandske kolleger argumenterede derudfra for, at enhver form for blanding i et menneske, ikke kun af fysiske, men også psykiske, adfærdsmæssige og seksuelle træk, var former for hermafroditisme, som måtte skyldes, at individet havde et blandet kønskirtelvæv, der producerede $b a ̊-$ de hanlige og hunlige hormoner.

Én af Europas fremmeste seksualforskere Magnus Hirschfeld havde opstillet fem forskellige kategorier af kønslige mellemstadier, der alle blev betegnet som variationer af hermafroditisme. Herunder regnede han bl.a. homosexualisme og biseksualitet, som han betegnede som uoverensstemmelse imellem det fysiske og det psykiske køn, og xgte såvel som pseudohermafroditisme, som han betegnede som en blanding af mandlige og kvindelige fysiske kønskarakteristika hos en person (Sand 1920, 1048; Fausto-Sterling 2000, 288 note 119; Sengoopta 2006, 77-79; Holm 2017, 194196). Også transvestisme, der af Hirschfeld blev defineret som en persons ubændige trang til at gå i det andet køns tøj, hørte til de kønslige mellemstadier, og her skelnede han imellem forskellige grader. Den mest ekstreme form for transvestisme var ifølge Hirschfeld, når en person ikke kun ønskede at skifte tøj, men ønskede at have en krop som det andet køn og blive fuldt accepteret af andre som værende af det køn (Hirschfeld 1910/1991, 182 og 198). Sand og de øvrige medlemmer af Retslægerådet gik i 1920'erne og 30'erne ud fra Hirschfelds definitioner, mens danske lægevidenskabelige eksperter fra 1940'erne begyndte at bruge betegnelsen genuin transvestisme som diagnose for personer, som ønskede at blive anerkendt $\mathrm{i}$ en anden kønsposition uden af kunne diagnosticeres som xgte eller pesudohermafroditter. Denne betegnel- se blev i slutningen af 1960'erne igen erstattet af betegnelsen transseksualitet (Holm 2017).

Omkring 1930, da Lili Elvenes gennemgik sin medicinske transition og Fra Mand til Kvinde blev skrevet, var spørgsmålet, som Retslægerådet fandt relevant for bedømmelsen af hendes sag altså, hvorvidt Einar Wegener, som ansøgte om opløsning af ægteskab og ændring af juridisk køn og navn, kunne betegnes som en xgte eller pseudohermafrodit eller som transvestit. Som Rosenbeck og Mørck nævner, bedømte Retslægerådet, at Wegener sandsynligvis "representerede et sexuelt Mellemstadium med stærk Tendens i kvindelig Retning" dvs. havde en form for fysisk hermafroditisk tilstand ifølge samtidens definitioner - men at de operationer, som Warnekros havde udført, gjorde det umuligt at bedømme, hvilken slags kønskirtler og genitalier ansøgeren havde haft tidligere, så det kunne ikke bestemmes med sikkerhed, til hvilken af de seksuelle mellemformer Wegener hørte (Meyer 2015, 285; Holm 2017, 349-350). På baggrund af dette blev ansøgerens ægteskab opløst ved dom, og et navneskift blev givet af Justitsministeriet fra Einar Wegener til Lili Ilse Elvenes. Denne beslutning var helt i overensstemmelse med gældende retspraksis siden begyndelsen af det 20. århundrede, hvor Justitsministeriet vejledt af Retslægerådet allerede adskillige gange havde givet tilladelse til navneskifte og juridisk kønsskifte til personer, der bedømtes til at have en form for hermafroditisk tilstand, der overvejende var i samme kønslige retning, som det juridiske køn, der blev ansøgt om (Holm 2017).

Så vidt de danske officielle og juridiske eksperter. Men hvad med transkvinderne? Mange historikere har argumenteret for, at Lili Elvenes og andre samtidige transkvinder simpelthen forsøgte at udnytte, at en del personer, der blev diagnosticeret som xgte eller pseudohermafroditter fik tilladelse til at skifte juridisk køn og fik lov til at blive opereret, så deres kroppe adskilte sig mindre fra 
andre mænds og kvinders (f.eks. Hausman 1995; Meyerowitz 2002; se også Meyer 2015; Stryker \& Whittle 2006). Jeg har i min afhandling i stedet kunnet se en anden mulighed: Eftersom der indtil slutningen af 1940'erne hverken fandtes nogen hverken medicinsk eller social opfattelse, der ligner den nutidige (at man kan være transkønnet), men i stedet en offentligt kendt medicinsk teori om fysiske og psykiske former for hermafroditisme, identificerede mange personer, som ud fra en nutidig forståelse var positioneret som transkvinder, sig som bermafroditiske kvinder, også når de selv og andre betragtede deres genitalier som værende mandlige.

Dette har jeg fundet adskillige eksempler på i selvbiografiske beretninger og lægefaglige eksperters rapporter allerede fra begyndelsen af 1920'erne, dvs. ti år inden Fra Mand til Kvinde blev udgivet og Lili Elvenes blev opereret. Af pladshensyn er det ikke muligt for mig at præsentere disse transkvinders historier her, men interesserede kan læse dem i min ph.d.-afhandling. For disse transkvinder gav medicinske teorier om hermafroditisme og om, at kønshormonproduktion styrede en persons følelser og oplevelse af deres køn, ofte mening til deres oplevelser af at føle sig som kvinder uanset, at de på basis af deres medfødte anatomi var blevet kategoriseret som drengebørn. Derudover gjorde teorierne det også muligt for transkvinderne at blive forståelige for andre mennesker som rationelle subjekter i sociale sammenhænge, ved at transkvinder kunne henvise til, at de ifølge disse teorier ikke skulle forstås som f.eks. homoseksuelle mænd, der fornægtede deres homoseksualitet eller led af en vrangforestilling om at være kvinde, men som personer, der kun tilsyneladende var mænd, men som biologisk set faktisk var heteroseksuelle kvinder, hvis krop ved en fejl havde udviklet sig i mandlig retning. Ud over dette kunne de pege på, at lægevidenskaben nu var i stand til også i høj grad at normalisere hermafroditiske kvinders kroppe uanset hvilken fysisk, herunder geni- tal, konstitution, man havde, til også anatomisk at komme nærmere hvad de selv og andre betragtede som en normal kvindekrop igennem kønskirteltransplantationer, plastiske operationer, og, fra midten af 1930'erne, terapi med syntetiske østrogener. De bevarede livshistorier vidner om, at begge dele havde stor betydning for, at en del transkvinder kunne blive socialt accepteret og dermed skabe sig et levbart liv som kvinder, der nok anatomisk var noget anderledes end andre kvinder, men ikke desto mindre kunne opleve sig selv og opleves af andre som psykisk og seksuelt normale.

De livshistorier, jeg har fundet på Rigsarkivet, såvel som fremstillingen af Lili Elbes historie i Fra Mand til Kvinde, kan dermed ses som tekster, hvor der fremstår en forbindelse imellem forskellige borgeres og lægefaglige eksperters forståelse af bestemte kønspositioner og -identiteter i første halvdel af det 20. århundrede. Kønspositioner og -identiteter, som først fra 1950'erne og 60 'erne blev italesat med de medicinske og psykiatriske kategorier interkønnethed og transseksualitet. Den forbindelse, der i de tidlige sager kan findes mellem forståelser af forskellige former for hermafroditisme og ønsket om et skift i kønskategori, er hidtil i høj grad blevet overset af historikere, som har forsket i Lili Elvenes' og andre transkvinders livshistorier. Dette på trods af, at det ofte er blevet nævnt, at mange transpersoner i den forste periode hævdede, at de var hermafroditter. I lyset af samtidens lægevidenskabelige teorier om hermafroditisme fremstår spørgsmålet, om Lili Elvenes egentlig var transkønnet eller interkønnet, anakronistisk. For hende, andre transkvinder og deres læger var det relevante spørgsmål ikke, om hun og de andre havde en hermafroditisk tilstand, men i hvilken grad og af hvilken art deres hermafroditisme var. De svar, som de i fællesskab etablerede, blev i hvert tilfælde ofte afgørende for, hvilket liv det blev muligt for den enkelte transkvinde at leve, og hvorvidt hun blev anerkendt af staten som kvinde eller ej. 


\section{LITTERATUR}

- Fausto-Sterling, A. 2000. Sexing the Body: Gender Politics and the Construction of Sexuality. New York: Basic Books.

- Hausman, B. 1995. Changing Sex: Transsexualism, Technology, and the Idea of Gender. Durham NC: Duke University Press.

. Holm, M. 2017. Fleshing Out the Self: Reimagining Intersexed and Trans Embodied Lives Through (Auto)biographical Accounts of the Past. Ph.d.afhandling, Linköpings universitet. Tilgængelig på http://liu.diva-

portal.org/smash/get/diva2:1095707/FULL-

TEXT01.pdf.

. Holm, M. \& Bülow, M. H. 2013. Det stof mænd er gjort af. Konstruktionen af maskulinitetsbegreber i forskningsprojekter om testosteron i Danmark fra 1910'erne til 1980'erne. Varia: Udgivelser fra Center for Konsforskning, 10: 1-221.

Available at: http://koensforskning.ku.dk/nyeudgivelser/varia/.

- Hirschfeld, M. 1910/1991. Transvestites: The Erotic Drive to Cross-Dress. Translated by Michael A. Lombardi-Nash. Amherst \& New York: Prometheus Books.

- Hoyer, N. (red.) 1931. Fra Mand til Kvinde: Lili Elbes Bekendelser. 4. oplag. København: Hage \& Clausens Forlag.
- Meyer, S. 2015. "Wie Lili zu einem richtingen Mädchen wurde"- Lili Elbe: Zur Konstruktion von Geschlecht und Identität zwischen Medicalisierung, Reguleierung und Subjektivierung. Bielefeld: Transcript Verlag.

- Meyerowitz, J. 2002. How Sex Changed: A History of Transsexuality in the United States. Cambridge MA \& London: Harvard University Press. . Oram, A. 2007. Her Husband was a Woman! Women's Gender-Crossing in Modern British Popular Culture. London \& New York: Routledge. . Sand, K. 1920. "Om moderne Sexualforskning [On modern Sexual Research]". Ugeskrift for Lager 82(33): 1045-1063.

- Sengoopta, C. 2006. The Most Secret Quintessence of Life: Sex, Glands, and Hormones, 1850-1950. Chicago: University of Chicago Press.

- Stryker, S. \& Whittle, S. (eds.) 2006. The Transgender Studies Reader I. New York: Routledge. - Tebbutt, C. 2014. Popular and Medical Understandings of Sex Change in 1930s Britain. Ph.d.-afhandling, University of Manchester. Tilgængelig på

http://ethos.bl.uk/OrderDetails.do?uin=uk.bl.ethos.686745. 


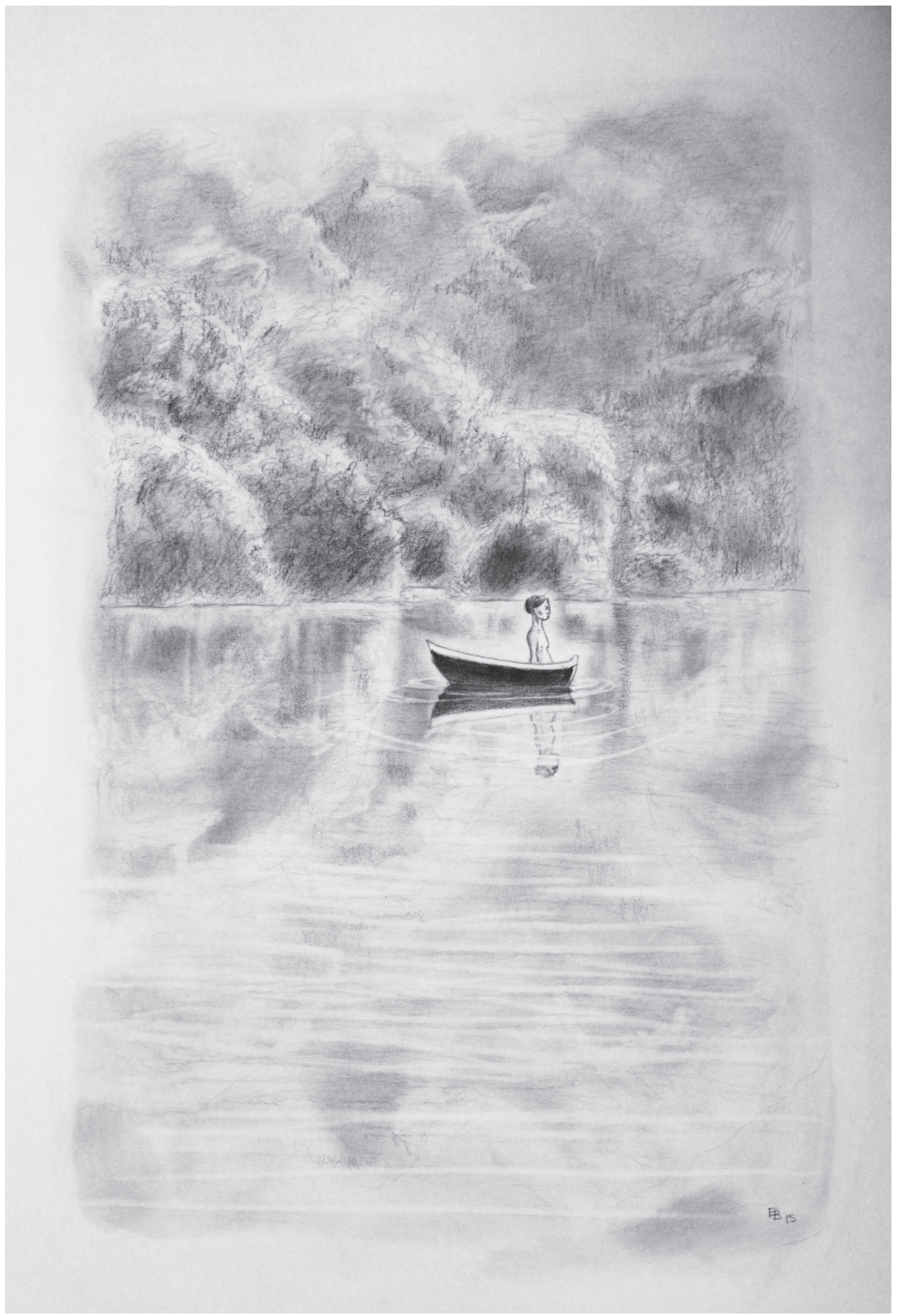

Ene Bissenbakker Frederiksen: Grow Up \#9, blyant og papir, www.enebissenbakker.com. 